\title{
HISTORICAL DISSERTATIONS DEFENDED IN 2010
}

\author{
Aelita Ambrulevičiūtė (Klaipėda University), Mažmeninė prekyba Vilniaus, \\ Kauno ir Gardino gubernijose 1861-1914 metais (tinklas, plètra, mo- \\ dernejjimas) [The Retail Trade in the Vilna, Kovno and Grodno Gubernias \\ in 1861-1914 (The Network, Expansion and Modernisation)]
}

The dissertation goes into microeconomics, with a focus on the socioeconomic development of society and the processes defining the evolution of the material culture, that is, the modernisation process of the lower strata of the economy is subjected to analysis. The aim of the research is to establish the development processes of the retail trade in Lithuania in the mid-19th and early 20th centuries through an investigation into the impact of the process of industrialisation on the evolution of retail trade, and the modernisation of its forms inside and outside Lithuania. The study also deals with the development of the organisation of trade, and changes, as well as features of the urban and rural networks of retail trade. The analysis covers the evolution in the relationships between production, wholesale and retail, and the reorganisation of the structure of domestic trade, highlighting the expansion of stock, and changes in usage and demand. In addition, it offers a picture of the legal regulation of trade institutions, indicating gaps in trade laws and their impact on the increase in unauthorised business relations.

Nerijus Babinskas (Vilnius University), Moldova XIV a. viduryje - XVI a. viduryje kaip socialinès struktūros tipologijos problema [Moldova in the Mid-14th to the Mid-16th Centuries as a Problem of Typology of Social Structure]

The main aims of the study were predetermined by Moldavian and Romanian historians, who, in the author's opinion, have presented no adequate conceptually reflected and adequately debated interpretation of the socio-economic structure of early Moldova based on the classic Marxist theory of production formations/modes. The dissertation combines two key Marxist approaches to universal history. The author also attempts to define 
explicitly the basic criteria facilitating the unambiguous typologisation of pre-capitalist societies. The definition has allowed the author to draw the main conclusion of the research, that the medieval social structure of Moldova cannot be viewed as a feudal mode of production, but should rather be defined as a hybrid of archaic semi-feudalism and communal politarism. Based on the Marxist world-systems theory, medieval Moldova can be typologised as follows: a) Moldova was part of the Europe-Middle East world economy, and thus should be considered a commercial and political economy; b) the exosocietal (external) factor was not significant enough, and thus should be disregarded, focusing exclusively on the result of endosocietal (internal) typology.

Kęstutis Bartkevičius (Vytautas Magnus University), Lietuvos persitvarkymo sąūūžio vietinio lygmens organizacijos 1988-1990 metais: struktūros ir socialinè analizė [Local Level Organisations of the Reform Movement of Lithuania Sajūdis in 1988-1990: A Structural and Social Analysis]

The dissertation offers an analysis of the Reform Movement of Lithuania (Sajūdis), its structure, motives for joining indicated by separate members, issues related to membership or non-membership, and a social picture of members of local and central structures of Sajūdis. The aim of the study is to describe and analyse the circumstances underlying the formation of local level organisations within Sajūdis, and the further development of its internal structure, and to investigate the social composition of the organisation and the ability of its members to participate in the power structures of Sajūdis (coordinating activities on local and national levels). The research reveals that in the period from 1988 to 1990, Sajūdis as an organisation consisted of 53 regional sub-organisations, with limited numbers of active (registered) members. The majority of them restricted their activities to support groups organised on a territorial and professional basis. Membership of local organisations of Sajūdis was generally applied for by citizens of the Republic of Lithuania, 21 to 50 years of age, who were born and educated under Soviet rule, including members of the Communist Party, former exiles and political prisoners.

Laima Bucevičiūtė (Vytautas Magnus University), Lietuvos Didžioji Kunigaikštystė XV-XVI a.: valstybès erdvès ir jos sienų samprata [The Grand Duchy of Lithuania in the 15th and 16th Centuries: The Concept of the State Domain and its Territorial Boundaries]

The study aims at analysing the concept of the state domain and the territorial boundaries of the Grand Duchy of Lithuania in the 15th and 16th centuries, based on narrative and cartographic sources, legal documents, 
and data related to boundary delimitation and demarcation. It analyses how state boundaries which existed or did not exist in reality were reflected and perceived in the population's consciousness. The research shows that the situation regarding the concept of borders with neighbouring countries was rather diverse, the tautest being with Livonia, the Teutonic Order and Poland. In the east, the procedures of territorial division were different, as no linear boundary concept was formed there, with the exception of several episodes on the Lithuania-Muscovy border. In the mental map of state consciousness, the most vulnerable points in the concept of the state domain and territorial boundaries are associated with the eastern and southern territories of Lithuania, regions with various political strains with unmarked real state borderlines.

Domininkas Burba (Vytautas Magnus University), Bajorijos kriminaliniai nusikaltimai ir bausmès Lietuvos Didžiojoje Kunigaikštystėje XVIII a. [Criminal Offences and Punishments of the Nobility in the Grand Duchy of Lithuania in the 18th Century]

This study, which is based on the example of the Vilnius powiat, discloses the structure of offences, their statistics, reasons and environment, the social background of offenders and their victims, the degree of violence and theory, and the handing out of punishments. An investigation of the offences committed by the ruling class of the period in question, the nobility, helps to analyse the society of the time, its conflicts and means for their resolution, and the relationships between the nobles and their peers and members of other social strata. The dissertation focuses on violent crime, such as homicide, acts intended to cause injury or pain (murder, battery, duel), the deprivation of liberty, sexual assault, estate raids, attacks on city households and robbery. The author also investigates punishments, including disgrace (deprivation of honour), banishment (exile), imprisonment and capital punishment. The thesis surveys the dynamics of crime, and suggests that the majority of offences were committed in rural areas. Even though the provisions of the Statute of Lithuania were rather strict, the judiciary and police control were insufficient: a number of crimes remained undiscovered and offenders were not punished.

Salvijus Kulevičius (Vilnius University), Lietuvos paveldosaugos idèjiniai modeliai ir jų raiška praktikoje sovietmečiu [Ideological Models of Lithuanian Heritage Protection and their Practical Implementation in the Soviet Period]

With regard to the fact that Soviet-period heritage protection is rather controversially viewed in Lithuanian historiography (either the achievements 
are praised and certain well-concealed forms of resistance are discerned, or huge losses in the heritage and Moscow's diktats are pointed out), the dissertation poses the question, to what extent are the origins of presentday heritage protection Lithuanian, and to what extent are they Soviet? The thesis focuses on the ideological fountainhead of heritage protection in the period in question, and the implementation of the ideas. The idea as the object of the research is perceived in the broadest sense of the word, covering theory and practice, official and unofficial concepts, and implemented and unimplemented projects. The research has brought the author to the conclusion that freedom of choice of ideological models in heritage protection in Soviet times was subject to the sphere of heritage protection, thus resulting in the heterogeneity of the ideological origins of Lithuanian heritage protection and the peculiar dynamics of its ideological models in the Soviet period.

Giedrè Sabaitytė (Vytautas Magnus University), Užribio žmonės Lietuvos Didžiosios Kunigaikštystès visuomenėje [Marginals in the Society of the Grand Duchy of Lithuania]

The dissertation aims to construct a theoretical model disclosing the tendencies accountable for the formation of groups of 'marginals' characteristic exclusively of the society of the Grand Duchy of Lithuania in the 16 th to 18th centuries. The hypothesis set forth in the study suggests that socio-cultural and socio-economic factors which determined the relations of society with the marginal phenomenon were the reason for the formation of specific mechanisms for becoming marginalised. These mechanisms conditioned the status of 'marginals' in society in the period in question, the degree of society's tolerance towards them, and the nature of the actions employed against them. People accused of witchcraft were deemed sociocultural outcasts, and serfs who had escaped from their masters represented 'outcast people' from a socio-economic point of view. The outcast status of those accused of witchcraft was predetermined by peculiarities of the social mentality, and the prevailing beliefs were accountable for the strong perception of the 'otherness' of marginal people, even leading to their physical destruction. Escaped serfs experienced a less hostile attitude by society, which did not deny them of possibilities to integrate into other spheres of life.

Agnė Vaitkuvienė (Vilnius Universitetas), Kultūros palikimo ịpaveldinimo procesai sovietinèje ir posovietinėje Lietuvoje [Processes of Cultural Inheritance in Soviet and Post-Soviet Lithuania]

The dissertation deals with an assessment of cultural heritage in Soviet and post-Soviet Lithuania, based on value-related rather than institutional 
models, and reveals the methods and principles of attributing values to objects of the cultural heritage during processes of conversion into heritage. It shows the pragmatic and demonstrative approach towards the formation of monument lists predominant in heritage assessment in the Soviet period, characterised by both Soviet and Lithuanian nationalist ideological aspects, and shows its correlation with the Western idea of monument protection. In addition, it surveys features of the formation of associative/symbolic, information, aesthetic and economic values. In the period following the restoration of Lithuania's independence, a tendency of object 'ageing' is observable, dismissing the Soviet legacy and prioritising the oldest possible heritage, thus aspiring to legitimise Lithuania's statehood. Moreover, the actualisation of new social and economic values of the heritage is discernible.

\section{Audronė Veilentienė (Vilnius University). Lietuvos Respublikos seimų} itaka užsienio politikai 1920-1927 metais [The Impact of the Seim of the Republic of Lithuania on Foreign Policy during the Period 1920 to 1927]

The study analyses the activities of the Seim of the Republic of Lithuania, the Commission for Foreign Affairs, parliamentary groups and separate members, and their impact on foreign policy in 1920-27. It also dwells on the relationship between the Seim and the Government in dealing with key issues in international relations, and the opinions that parliamentary groups and separate members of the parliament held on foreign policyrelated matters. The dissertation also aims to establish to what extent the Seim was influenced by public opinion and that of the opposition. It analyses the competence of the Seim, the role of the Constituent Assembly of Lithuania in the stabilisation of the country's international situation, and its participation in negotiations with Soviet Russia and Poland. The study offers an inquiry into the impact that the confrontation between parliamentary groups of the first Seim had on foreign policy, the activities of the second Seim, including the discussion and ratification of the Klaipeda Convention, and the influence of the opposition and the employment of unsuccessful negotiations with Poland and the Vatican in election debates. The author investigates the attitude of the third Seim on the foreign policy tasks which emerged following the Locarno Conference, the formulation of the agreement between Lithuania and the USSR, changes in the parliament after the 1926 coup, parliamentary discussions on the budget of the Ministry of Foreign Affairs, and the Seim's role in refining the structure of the Ministry. 
Julius Žukas (Klaipėda University), Klaipėdos krašto ekonominė raida XIX a. antrojoje pusẻje - XX a. pirmojoje pusėje (1871-1939) [The Economic Development of the Klaipeda Region in the Late 19th and Early 20th Century (1871-1939)]

This dissertation studies the economic development of the Klaipeda Region, and offers an analysis of changes in the economic life of the region in the political context of it being under the control of the German Empire (1871-1918), French administration (1920-22) and the Republic of Lithuania (1923-39). The main focus lies on industry and transport in the region, and the port of Klaipeda, presenting a detailed analysis of internal and external factors influencing key economic processes. For example, in the period under the German Empire, stagnation in the economic life of the region was observable, for the most part due to rivalry with Königsberg. French rule saw a certain activity in the economic life of Klaipeda, induced by the prospects of the region becoming a free state. The politically motivated Lithuanian and German economic sanctions introduced in the second half of 1922 resulted in a significant deterioration in business conditions in the Klaipeda region, and the Lithuanian government of the region is defined as a period strongly dependent on external and internal political factors. In general, Lithuanian economic policy in the region is viewed as having been adequate and in line with the interests of the state, but it caused confrontations between the economic interests of the local Germans and Lithuanians, and instigated social tensions in the region. 